\title{
Community Driven Development (CDD) and Rural Poverty Alleviation in Nigeria: A Bottom-up Development Approach
}

\author{
Odishika Vivian Anietem*, Adedeji Liadi Abiodun \\ Economics Unit, National Open University of Nigeria, Nigeria
}

Copyright $\bigcirc 2016$ by authors, all rights reserved. Authors agree that this article remains permanently open access under the terms of the Creative Commons Attribution License 4.0 International License

\begin{abstract}
Poverty alleviation programmes have been aggressively pursued by governments in developing world, with a lot of focus on government led approaches and initiatives - which in most cases have left much to be desired. The major thrust of this study is to analyze a number of selected rural development (community driven) projects. The paper uses literature collected from secondary source to analyze selected projects. The study shows that Community driven projects are indeed effective in improving the lives of the poor in rural areas by increasing their productive assets, income level and general welfare. This study recommends that for it to achieved desired results, community driven development approaches to rural poverty alleviation should be carefully planned and monitored.
\end{abstract}

Keywords Bottom-up, Community Driven Approach, Development, Poverty Alleviation, Rural Development

\section{Introduction}

POVERTY is a global issue of concern affecting both the developed and developing worlds (in either relative or absolute terms), but felt most in the developing world because it presents itself in absolute terms as a vicious circle very difficult to break. It is a multidimensional phenomenon which depicts various level/degree of deprivation. According to Development Assistance Committee (DAC) (2001), poverty encompasses different dimensions of deprivation that relate to human capabilities including consumption and food security, health, education, rights, voice, security, dignity and decent work. Sancho (1996) and World Bank (1995) in Osinubi, (2003) defined the poor as those who are unable to obtain an adequate income, find a stable job, own property or maintain healthy living conditions. They also lack an adequate level of education and cannot satisfy their basic health needs. As such, the poor are often illiterates, in poor health and have a short life span.

The Human Development Report (UNDP, 2011) revealed that most developing countries of the world scored low in life expectancy, literacy level and income as they occupied the bottom positions in their Human development index (indices of life expectancy, education and income) 2011 ranking, with Nigeria emerging as the $156^{\text {th }}$ out of the 187 countries listed in the report.

It is generally accepted that poverty the world over cannot be completely eradicated but it can be alleviated. Poverty alleviation has been a major economic concern of developing countries around the world with a lot of poverty alleviation strategies practiced over the years. Most of these poverty alleviation programmes have however focused mainly on the urban areas while neglecting the rural areas and from records available, we know that these rural areas are worse hit by poverty.

IFAD (2011) noted that global poverty remains a massive and predominantly rural phenomenon - with 70 per cent of the developing world's 1.4 billion extremely poor people living in rural areas of Sub-Saharan Africa and South Asia. In Nigeria, the World Bank in 1996 carried out a study to assess the poverty trend in Nigeria between 1985 and 1992 , the main findings of the study was that, poverty was more pronounced in rural than in the urban areas(World Bank 1996).

The reason for this widespread rural poverty is obvious as Olaitan et al (2000), rightly observed that in the rural areas, rural dwellers are under-served in terms of social and economic activities like welfare and other forms of reforms such as trade and industry; electricity and pipe borne water. According to him, the absences of these make them more prone to poverty.

Despite all efforts by various governmental and non governmental agencies to reduce poverty in the rural areas, a large percentage of them are still wallowing in poverty. Poverty in these rural areas means that a lot of these poor rural dwellers would eventually find a way to migrate to the few urban areas in search of greener pasture and this rural 
urban migration would worsen the conditions of the few cities by creating urban slums, large shanty towns and all the other problems associated with rapid urbanization.

As a result of the dangers posed by the failure of governments to take care of rural area people and their environments, the developing world has come under increasing pressure to explore new approaches to reduce the incidence of poverty in these areas and hence the birth of community driven development poverty alleviation programmes. This is a bottom up approach which seeks community participation in projects that are designed to alleviate poverty in these areas, with the aim of achieving a solution to the overall national poverty alleviation by starting from the grassroots with the community taking the lead in initiating the projects. The paper will assess the impact of a bottom up community driven development approach on poverty alleviation in rural areas with a special focus on Nigeria. It will analyze the successes and failures of some selected community driven poverty alleviation projects embarked upon by various organizations in different parts of the world, with the aim of finding the best ways to handle a poverty alleviation programme in order to achieve the best results.

\section{Literature Review}

Community development includes all strategies, interventions or coordinated activities at the community level aimed at bringing about social and economic development (Idode,1989 in Akpomuvie, (2010). Development planners for several decades adopted approaches which were essentially top-down in nature, with donors and central national authorities dominating the entire process. This non- participatory model did not yield optimal results (Chebil and Haqu2001). Chebil and Haqu, (2001) also noted that the top down approach is generally based on the assumption that the poor would definitely benefit greatly from the mere phenomenon of economic growth. For a rural development programme to effectively alleviate poverty, it must have the following qualities: Pro poor, sustainable, and must be able to empower the poor (Livingstone, 2008; Naryan, 2002 and Chebil and Haqu 2001). All these are what the community driven development approach stands for. The United Nations (1956) defines Community Driven Development Approach as the process by which the efforts of the people themselves are united with those of the governmental authorities to improve the economic, social and cultural conditions of the communities, to integrate these communities in the life of the nation and enable them to contribute fully to national progress.

Several researches have been carried out to analyze the relationships between community participation in project/ programmes and poverty reduction with most of them proving that there is actually a positive link between them.

King and Orazem (1999), in their analysis of community driven school projects in India and El Salvador, found out that Community participation helped curb absenteeism among school teachers in the area as community people whose children were in the schools helped monitor the activities of the teachers. Others are, Owen and Von Domelen (1998). Folke (2006) conducted a study on a community based project- Bangladesh's CBA coastal afforestation project which aimed at educating people, providing physical infrastructure and established cooperatives for poor men and women, found out that despite all of the projects efforts, the region is still one of the poorest in Bangladesh (Folke in Folke and Nielsen. 2006). Researchers have done so much on Community Driven Development (CDD) in isolated form however; this paper identifies key principles, successes and shortcomings of some selected projects (c a s e study) in order to find the ways the approach can be practiced.

\section{Rural Development in Nigeria}

Rural areas of a region or country lie outside the denselybuilt up environments of towns, cities and sub-urban villages and their inhabitants are engaged primarily in agriculture as well as the most basic of rudimentary form of secondary and tertiary activities (Adebayo 1998) These areas are characterized by

- little or no infrastructural facilities

- high birth and death rates

- large percentage of children and the aged

- majority of population involved in crude subsistence

- farming and petty trading and sadly,

- general high level of poverty

- high level of illiteracy

A number of development approaches have been pursued by various governments in Nigeria with the aim of alleviating rural poverty, some of which are:

- Directorate for Food, Roads and Rural Infrastructure (DFRRI)

- Better Life Programme for Rural Women/ Dwellers

- Family Economic Advancement Programme (FEAP)

- National Poverty Eradication Programme (NAPEP)

In Nigeria the major reason why the rural areas have a majority of their population below the poverty line is the long neglect of these areas by the government. According to Akpan (2012), the early years of Nigeria's independence witnessed colossal concentration of development efforts on the modern sector of the economy to the exclusion of investment in the rural economy. Most of the above mentioned programmes were mainly government led initiatives with no real community participation hence they are top-down in nature. According to World Bank (1999b), people have a right to partake in actions and plans which affect their lives as non participation approaches to development have failed to significantly alter the quality of life and resources of the poor people worldwide. As a result 
of the failure of the Top Down developmental approaches of past governments in tackling rural poverty and the dangers posed by rural urban migrations, CDD programmes became popular with time in Nigeria, examples of these projects are Fadama II (which received the 2008 World Bank Africa Award for Excellence) and FADAMA III . These projects are Community-Based Rural Development Programmes which focused on working with community groups to achieve sustainable development.

\section{Community Driven Development Approach}

Community development includes all strategies interventions or coordinated activities at the community level aimed at bringing about social and economic development (Idode, 1989). The salient features are:

- It is demand driven

- It encourages analysis of local problems with a view to improving the level of living standards

- It considers the local community, as the basic unit for planning and development; It provides technical and other services in ways which encourage initiative and cooperation and

- It diffuses the decision-making power by emphasizing the principle that those affected by community change should themselves select and manage such change

\section{Theoretical Framework}

The theory of this paper hinges upon the General System Theory ((GST) propounded by Ludwig von Bertalanffy (1968). The theory provides an analytical framework which can be used to describe various activities involved in community development project.

The basic concepts are as follows:

- Assessing the community;

- Selecting development goals;

- Planning a strategy to reach those goals;

- Carrying out activities to achieve goals, and;

- Evaluating progress and including the results of evaluation in subsequent activities.

\section{Case Study}

\section{Project 1}

The Kecamatan Development Programme (KDP) in Indonesia-the world's largest CDD programme- which ran from 1998-2009

\section{Key Principles}

- Transparency: KDP emphasized transparency and information-sharing throughout the project cycle. Decision- making and financial management was open and shared with the community.

- Participation/ Inclusion: Community participation was emphasized, especially among the poor and women. Participation was broad-based, through local decision-making by all villagers.

- Open Menu: Villagers were allowed to propose any activity, except for those on a negative list.

- Competition for Funds: There was open, healthy competition between villages for KDP funds.

- Simplicity: No complex rules, just simple strategies and methods.

- Decentralization: Decision-making and management occurred at the local level.

\section{Programme Result}

The programme had directly benefited an estimated 18 million people (as at December 2006).

As at 2008, the programme had covered 32 of 33 Provinces, benefiting 38,000 villages.

The programme provided better basic infrastructure, including around 37,000 kilometers of local roads and 8,500 bridges, 9,200 clean water supply units, and 3,000 new or improved health posts.

Through micro-financing, more than 1.3 million people obtained loans to start or complement local businesses.

Around 101,500 young people received scholarships to attend school and 5,100 schools were built or rehabilitated (World Bank 2011, IDA-CDD 2009, and Malhotra 2003).

\section{Project 2}

Bonadikombo, Limbe Community (Cameroon) participation in the supply of water (1973-1981)

\section{Key Principles}

Contribution: By contributing, residents increased their sense of ownership over the project, which would not have happened if the project was funded completely by external bodies.

Cooperation: Cooperation was critical to the project's success given that the source of water for the project was located in a different community

Consultation: consultation in this project entailed passing out information to, and receiving feedback from, members of the community through Town Hall meetings and the interviewing of local leaders.

\section{Result}

The region now enjoys improved access to potable water, affordable water services and the project has also proved to be sustainable because it has been in operation since 1981 . The project had a focus on issues such as finance and physical resources neglecting other aspects like decision making procedures, community empowerment and monitoring. As a result, the programme failed to strengthen 
the skills, competencies and abilities of the people.

\section{Key Principles}

- Capacity Building: Built the capacity of users by encouraging full scale participation in attending trainings organized by programme facilitators on capacity building.

- Provision of Demand-responsive: The advisory services that enabled Fadama resource users to adopt output-enhancing techniques and more profitable marketing practices in their enterprise.

- Pro-Poor Approach: The project targeted the poor and vulnerable focusing specially on groups of youth, women (especially widows), the disabled, the elderly, and people with HIV/AIDS ( Nkonya et al 2010; Muhammed et al.,2011)

- Multipurpose Approach: The programme was broad-based, (Multipronged) touching several constraints limiting the success of a CDD project. The idea is that since the poor have lots of constraints making and keeping them poor, for a project to succeed, it has to put into consideration the key issues that are likely to hinder its success.

\section{Result}

- Household incomes improved substantially more for Fadama II beneficiaries than for non-beneficiaries, with an average increase in real income resulting from participation in Fadama II of about $60 \%$ far above the targeted $20 \%$.

- The Fadama II project recorded a great level of spillover effects in the areas the project covered.

- It failed to increase the private owned production assets of the very poor and women as noted earlier on, this was due to their inability to pay for the compulsory contributions required to acquire these assets

\section{Study Findings}

- All the Projects were geared towards meeting the development needs of the poor. And these needs were induced by the communities involved.

- Complete Community participation in projects promoted capacity building in the people because it strengthened their skills, competencies and abilities.

- The CDD projects promoted sustainability, because the beneficiaries contributed (cash /Labour) to the projects and this gave the people a sense of ownership.

- The projects were simple

- Cooperation( at the federal, state and even within the communities) was key in all the projects

- The evaluation of projects by the community after completion helped create and improve future projects e.g. FADAM II and III in Nigeria

- A multipronged project is more effective in alleviating poverty than a single or double based project.

\section{Recommendations}

- There must be clearly defined target groups

- There is a need for consistency to be between project goals and national goals

- Elite capture risk - in which a few influential individuals in a local community having political or economic power prevented the benefits of CDD projects

- Government should know its place as far as CDD is concerned. Projects should be demand driven and not supply

- Mandatory contributions for project in CDD programmes should be made as affordable as possible

- Accountability should be encouraged so that funds get properly used

\section{REFERENCES}

[1] Adebayo, A (1998)Urban Bias in Nigerian Development Planning', The Nigeria Journal of Economic and Social Studies, vol. 19 (1)

[2] Akpomuvie, O (2010) - Self-Help as a Strategy for Rural Development in Nigeria: A Bottom- Up Approach \|. Pakistan Journal of Social Sciences, Volume: 6

[3] Aliyu, U.K (2004). A Welcome Address Delivered at the Training Workshop for Facilitators and Officers in Local Fadama Desks, held at Abdulsalam Abubakar Youth

[4] African Development Fund ADF (2003) Federal republic of Nigeria community based agricultural and rural development project appraisal report. July

[5] African Development Fund (ADF), Federal Republic of Nigeria, Community Based Agriculture and Rural Development Project Appraisal report. (July 2003)

[6] Akinboyo, O 2012 - Towards Jobs creation and Poverty Reduction through an Effective Policy coordination in the Agricultural sector of the Nigerian Economy $\|$. Paper presented at the $53^{\text {rd }}$ Annual Conference of the Nigerian Economic Society.

[7] Akpan , N 2012 —Rural Development in Nigeria: A Review of Pre- and Post-independence Practice II. Journal of Sociological Research, Vol. 3, No. 2.

[8] Chebil, S \&Haque I 2001 -Community driven development programs for poverty reduction: Experiences, Issues, and Lessons $\|$ Journal of Alternative Perspectives in the Social Sciences Vol. 2, No 1

[9] Cheshire, P \& Gordon, I. 1996 - Territorial competition and the predictability of collective (in)action", International Journal of Urban and Regional Research, Vol. 20 http://dx.doi.org/10.1111/j.1468-2427.1996.tb00324.x

[10] Corona P 2012 - Local Economic Development in Mexico : The Contribution of The Bottom-Up Approach II. A thesis submitted to the Department of Geography and Environment of the London School of Economics and Political Science for the degree of Doctor of Philosophy. 
[11] Crescenzi, R \& Rodríguez-Pose, A (2008) - Infrastructure endowment and investment as determinants of regional growth in the European Union II .EIB Papers, vol. 13,2

[12] Development Assistance Committee (DAC) (2001) Rising to the Global Challenge: Partnership for Reducing World Poverty. Policy Statement by the DAC High Level Meeting upon Endorsement of the DAC Guidelines on Poverty Reduction. Paris, 26-28 April

[13] Folke, S \& Nielsen, H (2006) -Aid Impact and Povert y Reduction $\|$. Palgrave Macmillan. New York http://dx.doi.org/10.1057/9781403984555

[14] IDA 2009 -Community-Driven Development: Delivering the Results People Need \|| The World Bank. July, 2009

[15] Idode, J (1989) Rural Development and Bureaucracy in Nigeria. Ibadan; Longman, Nigeria.

[16] IFAD International fund for agric development (2010)Federal republic of Nigeria Country strategic opportunities programmeoperations.ifad.org/web/ifad/operations/country/. ../Nigeria

[17] IFAD 2011 Rural Poverty in Nigeria. http://www.ruralpove rtyportal.org/web/guest/country/home/tags/nigeria. International Fund for Agricultural Development

[18] IFAD International Fund for Agric development 2010 Federal Republic of Nigeria Country strategic opportunities programmeoperations.ifad.org/web/ifad/operations/country/. ...Nigeria

[19] Ijere, M.O. (1990): Prospects of Nigerian Cooperatives Centre for rural development and Cooperatives, University of Nigeria, Nsukka

[20] King, Elizabeth and P. Orazem.(1999) Evaluating Education Reforms; four Cases in Developing Countries, World Bank, Washington, D.C.

[21] Livingstone D 2008 -Community Development Through Empowerment of the Rural Poor \| Journal of Policy Development and Research, vol.2

[22] Malhotra, M (2003) World Bank Institute (WBI)Learning from the Kecamatan Development Program (KDP)The first Shanghai Field Visit:Dec 7 - 9, 2003, Malang, Indonesia

[23] Muhammad H.U. et al., (2011) Assessment of Factors Influencing Beneficiary Participation in Fadama II Project in Niger State, Nigeria

[24] Narayan, D ( 2002) -Empowerment and Poverty Reduction II : A Source book for The World Bank. Washington D.C

[25] National Fadama Development Office (NFDO). 2005. Poverty reduction through increased productivity and empowerment. Abuja, Nigeria: NFDO, Project Coordination Unit

[26] National Fadama Development Office (NFDO). (2005). Poverty reduction through increased productivity and empowerment. Abuja, Nigeria: NFDO, Project Coordination Unit.

[27] Njoh, A (2003) The Role of Community Participation in Public Works Projects in LDCs: The Case of the Bomadikombo, Limbe(Cameroon) Self-Help Water Supply Project International Development Review
[28] Nkonya E, Philip D, Mogues T, Pander J, Yahaya M, Adebowale G, Arokoyo T,\& Kato E (2008).

[29] Community-Driven Development in Nigeria \| IFPRI discussion Paper 00756, IFPRI Washington

[30] Nkonya E. et al. (2010) -From the Ground Up Impacts of a Pro-Poor Community-Driven Development Project in Nigeria \|. International Food Policy Research Institute Discussion paper.

[31] Obetta, K \&Okide, C (2011) -Rural Development Trends In Nigeria: Problems And Prospects II. Journal of Society for Research and Academic Excellence.

[32] Osinubi, T. (2003) -Urban Poverty in Nigeria: A Case Study of Agege Area of Lagos State, Nigeria II . Global Development Network: GDN Knowledge Base. Produced by the Environmental and Societal Impacts Group (ESIG).

[33] Owen D \& Von Domelen J (1998) "Getting an earful II : A review of beneficiary assessments of social funds. Social Protection Team, Human Development Network. Washington, D.C.: World Bank.

[34] Pike, A., Rodriguez-Pose, A. and Tomaney, J., (2006).Local and regional development. Routledge, New York

[35] Swinburn, G (2006) -Local economic development \| A Primer Developing and implementing local economic development strategies and action plans. The World Bank, Washington, D.C.

[36] United Nations Development Programme (2001) Development of clusters and networks of SME's. The UNIDO Programme, Vienna.

[37] United Nations Organisation (1956) Twentieth Report of the Administrative Committee on Coordination to the Economic and Social council, 24th Session, Annex III, Document E/2931, Oct 18 .

[38] Tunrayo, A (2009) -Effects of Community Based Organizations Activities on Poverty Alleviation Local in Yewa south Government Area of Ogun State II Nigeria

[39] World Bank (1996) - Nigeria Poverty in the Midst of Plenty, the Challenge of Growth with Inclusion \| A World Bank Poverty Assessment Handbook 1996

[40] Williams, S. (1978) \| Rural Development in Nigeria ॥. Ife; University of Ife Press

[41] World Bank 1999a Second national Fadama development project implementation document. Assisted by the World Bank, Washington, DC, USA, pp. 1-110.

[42] World Bank. 1996b - Nigeria: Poverty in the midst of plenty - The challenge of growth with inclusion $\|$. Report No. 14733 UNI, Washington, D.C. (May).

[43] World Bank 2011 -Social development in east Asia Indonesia Kecamatan Development”.web.worldbank.org. Projects \& Programs

[44] Yakubu, O \&Aderonmu J (2010) \| Rural poverty alleviation and democracy in Nigeria's fourth Republic (1999-2009) \|. . Current Research Journal of Social Sciences vol. 2 (3) 